\title{
A New Approach to Cooling and Prilling during Fertilizer Manufacture
}

\author{
Ahmet Ozan GEZERMAN (Corresponding author) \\ Yildiz Technical University, Chemistry- Metallurgical Faculty, Istanbul, Turkey \\ Tel: 90-532-653-8505 E- mail: ahmet_ozan@yahoo.com \\ Burcu Didem CORBACIOGLU \\ Yildiz Technical University, Chemistry- Metallurgical Faculty \\ Istanbul, Turkey
}

Received: September 30, 2010 Accepted: October 15, $2010 \quad$ doi:10.5539/ijc.v3n2p158

\begin{abstract}
Developing different methods for obtaining the most products at economical rates from the available agricultural area has been necessary to satisfy the food needs of the fast- increasing population of the world by 17-th century. Accordingly, among the various alternative methods, chemical fertilizers have played a big part in the food revolution, and the fertilizer quality affects the new race of the environment toward market needs.

In our work, we tried to improve the fertilizer quality, during the prilling process, by referring to an already available downstream system; the temperature - phase relationship of the prilled fertilizers was investigated, and physicochemical properties were calculated for improving fertilizer- storage conditions. We worked on ammonium nitrate crystals in this study.
\end{abstract}

Keywords: Ammonium nitrate, Atomic bond strenght, Crystal unit, Downstream

\section{Introduction}

Nitric acid $\left(\mathrm{HNO}_{3}, 55 \%\right)$ and ammonia (anhydrous, 99\%) are used as raw materials for ammonium nitrate $\left(\mathrm{NH}_{4} \mathrm{NO}_{3}\right)$ fertilizer production by downstream process. The term "downstream" in manufacturing refers to the processes that occur later on in a production sequence or down the production line. The reaction scheme was shown in Scheme-I.

\section{Calculations}

The temperature before prilling for NH4NO3 production by the downstream process is given as follows (Derbentli, 1996, pp.137):

$$
\Delta \mathrm{H}=\mathrm{Cp} * \Delta \mathrm{T}
$$

$\left.\Delta \mathrm{H}_{(\mathrm{NH} 4 \mathrm{NO})}=5808 \mathrm{cal} / \mathrm{mol}, \mathrm{Cp}_{(\mathrm{NH} 4 \mathrm{NO} 3}\right)=0.484 \mathrm{cal} / \mathrm{g}$ 0C (Jacobsen, Lemmon, Penoncello, Shan, \& Wright, 2000, pp. 140-152).

$5808 \mathrm{cal} / \mathrm{mol}=0.484 \mathrm{cal} / \mathrm{g} 0 \mathrm{C} *\left(\mathrm{~T}_{2}-25\right)$

$\mathrm{T}_{2}=175^{0} \mathrm{C}$.

The amount of energy required for cooling the fertilizer from this temperature to room temperature is (Derbentli, 1996, pp.137),

$$
Q=\mathrm{m}^{*} \mathrm{Cp} * \Delta \mathrm{T}
$$

Let us calculate the change in energy for the temperature decrease from $175{ }^{\circ} \mathrm{C}$ to $25{ }^{0} \mathrm{C}$. This will give us the power of the cooling motors.

$$
Q=\mathrm{m}^{*} \mathrm{Cp} * \Delta \mathrm{T}
$$

where

$Q=$ heat transfer

$\mathrm{m}=$ mass of $\mathrm{NH}_{4} \mathrm{NO}_{3}$ 
$\mathrm{Cp}=$ specific heat of $\mathrm{NH}_{4} \mathrm{NO}_{3}$ at $25^{\circ} \mathrm{C}$

$\Delta \mathrm{T}=$ temperature difference

$=(100 \mathrm{t} / \mathrm{h}) *\left(0.484 \mathrm{cal} / \mathrm{g} *{ }^{0} \mathrm{C}\right) *(175-25){ }^{0} \mathrm{C}$

$=(100 \mathrm{t} / \mathrm{h}) *(1000 \mathrm{~kg} / \mathrm{t}) *(1 \mathrm{~h} / 3600 \mathrm{~s}) *\left(0.484 \mathrm{cal} / \mathrm{g}^{0} \mathrm{C}\right) *(4.18 \mathrm{j} / \mathrm{cal}) *(1 \mathrm{~W} * \mathrm{~s} / \mathrm{j}) *(1000 \mathrm{~g} / \mathrm{kg}) * 150{ }^{0} \mathrm{C}$

$=56.25 \mathrm{~kW}$

If four motors possesing $56,25 \mathrm{~kW}$ power and two motors of similar range are places on top and at the bottom of the prill tower, respectively, this increases the cooling speed by forcing the particles to remain on the air longer.

In cylindrical system, when we place four $56.25 \mathrm{~kW}$ motors against each other, and if the same influence is exerted by the system on every particle of the fertilizer, the calculations will be as follows (Kakac, \& Yuncu, 1999, pp.183):

$$
\mathrm{Q}=\mathrm{h} * \mathrm{~A} * \Delta \mathrm{T}
$$

where

$\mathrm{Q}=$ heat transfer by convection

$\mathrm{h}=$ heat transfer coefficient by convection for $\mathrm{NH}_{4} \mathrm{NO}_{3}=0.149 \mathrm{cal} / \mathrm{s}^{*} \mathrm{~m}^{2 *}{ }^{0} \mathrm{C}$ (Jacobsen, Lemmon, Penoncello, Shan, \& Wright, 2000, pp.140-152).

$\mathrm{A}=$ cylindrical area, $\mathrm{m}^{2}$

$56.25 \mathrm{~kW}=\left(0.149 \mathrm{cal} / \mathrm{s}^{*} \mathrm{~m}^{2} * 0 \mathrm{C}\right) * \mathrm{~A} *(175-25){ }^{0} \mathrm{C}$

$\mathrm{A}=2516 \mathrm{~m}^{2}=2 * 3.14 * r * h$

$r * h=400 \mathrm{~m}^{2}$

We can deduce the values of $r$ and h. For example, according to this formula, if radius $(r)$ is $10 \mathrm{~m}$, the height $(h)$ would be $40 \mathrm{~m}$.

Also, influence of motors on temperature of the fertilizer will be as follow (Kakac, \& Yuncu, 1999, pp.189):

$$
\left(\mathrm{T}_{1}-\mathrm{T}_{2}\right) /\left(\mathrm{N}^{*} h\right)
$$

where

$\mathrm{T}_{1}=$ initial temperature of fertilizer at the prill tower

$\mathrm{T}_{2}=$ final temperature of fertilizer at the prill tower

$\mathrm{N}=$ number of cooling motors

$h=$ height of the prill tower

$\left(175{ }^{0} \mathrm{C}-25{ }^{\circ} \mathrm{C}\right) /(4$ motors $* 40 \mathrm{~m})=0.9375{ }^{\circ} \mathrm{C} /$ motor. $\mathrm{m}$

First, we carry out the calculations of a four- motor system.

$\mathrm{T}_{3}=$ temperature of second phase change $($ tetragonal $)=125^{\circ} \mathrm{C}$

$\mathrm{x}_{1}=$ height of substance that has reached second phase ( tetragonal)

$\left(\mathrm{T}_{1}-\mathrm{T}_{3}\right) / 4 * 40=(175-125){ }^{0} \mathrm{C} / 4$ motors $*\left(40-\mathrm{x}_{1}\right) \mathrm{m}=0.9375{ }^{0} \mathrm{C} /($ motors*m)

$50{ }^{0} \mathrm{C} / 4$ motors $*\left(40-\mathrm{x}_{1}\right)=0.9375^{\circ} \mathrm{C} /($ motors $* \mathrm{~m})$

$\mathrm{x}_{1}=26.67 \mathrm{~m}$

This is the value when we consider the first phase conversion at the highest point of the tower as a reference.

Next, when we apply vacuum force with four motors, as the fertilizers go down the $13.33 \mathrm{~m}$ height ( from $175^{\circ} \mathrm{C}$, $40 \mathrm{~m}$ to $\left.125^{\circ} \mathrm{C}, 26.67 \mathrm{~m}\right)$, the second crystalline phase change occurs.

The temperature of the third change ( orthorhombic $)=84.5^{\circ} \mathrm{C}$

$\mathrm{x}_{2}=$ height of substance that has reached third phase ( orthorhombic)

$(125.0-84.5) / 4 *\left(13.33-\mathrm{x}_{2}\right)=0.9375$

$40.5 / 4 *\left(13.33-\mathrm{x}_{2}\right)=0.9375$

$\mathrm{x}_{2}=2.53 \mathrm{~m}$

The formation of the tetragonal structure ends at $10.8 \mathrm{~m}$ above the ground, as the substance descends from 13.33 
to $2.53 \mathrm{~m}$.

Temperature of the fourth phase change ( orthorhombic) $=32{ }^{\circ} \mathrm{C}$

$\mathrm{x}_{3}=$ height of substance that has reached fourth phase ( orthorhombic)

$(84.5-32.0) / 4 *\left(10.8-\mathrm{x}_{3}\right)=0.9375$

$28.84=10.8-\mathrm{x}_{3}$

$\mathrm{x}_{3}=-18.04 \mathrm{~m}$

$18.04-10.8=7.24 \mathrm{~m}$.

According to this result, the prill tower should be taller than $7.24 \mathrm{~m}$ to reach $32{ }^{\circ} \mathrm{C}$

Under these conditions, when the fertilizer leaves the tower, it will have the orthorhombic shape.

Second, we will consider by a six- motor system.

$\left(\mathrm{T}_{1}-\mathrm{T}_{2}\right) / 6 *(40)=0.9375$

We will next carry out the calculations for the six- motor system at the stage where the influence of all the sixmotors is lost.

$\mathrm{x}_{4}=$ height of substance that has reached first phase change at the prill tower with six- motors

$(175-125) / 6 *\left(40-\mathrm{x}_{4}\right)=0.9375$

$\mathrm{x}_{4}=31.1 \mathrm{~m}$

The first phase change in the tower occurs at $8.88 \mathrm{~m}$ ( while going down from $40 \mathrm{~m}$ ).

$(125.0-84.5) / 6 *\left(8.88-\mathrm{x}_{5}\right)=0.9375$

$\mathrm{x}_{5}=1.68 \mathrm{~m}$, the second phase change is completed at $7.2 \mathrm{~m}(8.88-1.68=7.2 \mathrm{~m})$

$(84.5-32.0) / 6 *\left(7.2-\mathrm{x}_{6}\right)=0.9375$

$\mathrm{x}_{6}=-2.13 \mathrm{~m}$

We cannot see the third phase change in the tower because of the height. However, when the prilled fertilizers leave the tower, they are in the orthorhombic phase. Our aim is to determine which system yields the most solids phase before the prilled fertilizer leaves the tower. Because a higher tower $(7.24 \mathrm{~m})$ is needed in the four- motor system and we obtain more of the solid phase using a smaller tower, the six- motor system is preferable.

We can calculate how long the substance should remain in air at each height range. Some exceptions should be allowed for these. For example, we can calculate the staying time on air from the formula $\mathrm{h}=\mathrm{Vo}^{2}+1 / 2$ $\mathrm{gt}^{2}$ (Kucuksahin, 1989, pp.87), where Vo, initial velocity; g, gravity; and t, time. When we calculate this value, we can neglect Vo2, because the speed of fall along the vertical axis tends to zero and the prilling fertilizer drops in a free fields.

According to this statement,

The time spent on the phase conversion of each crystal case form in the four- motor system is calculated as follows:

As the temperature decreases from 175 to $125^{\circ} \mathrm{C}$, the prill passes through a height of $26.67 \mathrm{~m}$. Then, $26.67=1 / 2$ $9.81 \mathrm{t}^{2} \rightarrow \mathrm{t}=2.33 \mathrm{~s}$

As the temperature decreases from $125.0{ }^{\circ} \mathrm{C}$ to $84,5{ }^{\circ} \mathrm{C}$, the prill passes through a height of $2.53 \mathrm{~m}$. Then, $2.53=$ $1 / 29.81 \mathrm{t}^{2} \rightarrow \mathrm{t}=0.71 \mathrm{~s}$

As the temperature decreases from $84.5{ }^{\circ} \mathrm{C}$ to $32.0{ }^{\circ} \mathrm{C}$, the prill passes through a height of $18.04 \mathrm{~m}$. Then, $18.04=$ $1 / 29.81 \mathrm{t}^{2} \rightarrow \mathrm{t}=1.91 \mathrm{~s}$

The time spent for coming to the point from which prill can be dropped free by removal from the prilling case at $175{ }^{\circ} \mathrm{C}$ is calculated as follows:

$$
\mathrm{h}=\mathrm{V}_{\mathrm{o}} \mathrm{t}+1 / 2 \mathrm{gt}^{2}
$$

We can reflect for an average $30 \mathrm{~cm}$ radius at $160 \mathrm{rpm}$. Then,

$2 * 3.14 * 30=188.4 \mathrm{~cm}$

160 rotations $/ \mathrm{min} *(188.4 \mathrm{~cm} /$ rotation $) *(1 \mathrm{~min} / 60 \mathrm{~s})=502,4 \mathrm{~cm} / \mathrm{s}^{*}(1 \mathrm{~m} / 100 \mathrm{~cm})=5.024 \mathrm{~m} / \mathrm{s}$

$\mathrm{V}_{\mathrm{o}}=5.024 \mathrm{~m} / \mathrm{s}$ 
This velocity should be used at lengths equal to the radius of the prilling tower.

$h=(5.024 \mathrm{~m} / \mathrm{s}) \mathrm{t}-1 / 29.81 \mathrm{t}^{2}=10 \mathrm{~m}=5,024 \mathrm{t}-4.905 \mathrm{t}^{2} \rightarrow \mathrm{t}^{2}=3.107 \rightarrow \mathrm{t}=1,76 \mathrm{~s}$

Thus, the time spent by the prill to move in the horizontal direction after leaving the prilling case is $1.76 \mathrm{~s}$

This value is applicable for both six- motor and four- motor systems.

Because of the fact that a six- motor system is preferable to a four- motor one, we will carry out further calculations for the six- motor system.

As the temperature decreases from 175 to $125^{\circ} \mathrm{C}$, the prill passes a height of $31.1 \mathrm{~m}$. Then, $31.1=1 / 29.81 \mathrm{t}^{2} \rightarrow \mathrm{t}=$ $2.51 \mathrm{~s}$

As the temperature decreases from 125 to $84,5{ }^{0} \mathrm{C}$, the prill passes a height of $1.68 \mathrm{~m}$. Then, $1.68=1 / 29.81 \mathrm{t}^{2} \rightarrow \mathrm{t}$ $=0.58 \mathrm{~s}$

As the temperature decreases from 84,5 to $32{ }^{\circ} \mathrm{C}$, the prill passes a height of $9.33 \mathrm{~m}$. Then, $9.33=1 / 29.81 \mathrm{t}^{2} \rightarrow \mathrm{t}=$ $1.37 \mathrm{~s}$

In a four- motor system,

from the formula $h=V_{0} t-1 / 2 \mathrm{gt}^{2}$

the substance spends $2.85 \mathrm{~s}$ at $175^{\circ} \mathrm{C}$ without phase conversion

$26.67=1 / 29.81 \mathrm{t}^{2} \rightarrow 2.33 \mathrm{~s}$

$40.00-26.67=13.33=1 / 29.81 \mathrm{t}^{2} \rightarrow \mathrm{t}=1.65 \mathrm{~s}$

$2.53=1 / 29.81 \mathrm{t}^{2} \rightarrow 0.718 \mathrm{~s}$

$13.33-2.53=10.8 \mathrm{~m}=1 / 29.81 \mathrm{t}^{2} \rightarrow \mathrm{t}=1.48 \mathrm{~s}$

$18.04 \mathrm{~m}=1 / 29.81 \mathrm{t}^{2} \rightarrow \mathrm{t}=1.91 \mathrm{~s}$

In a six- motor system,

$40=1 / 29.81 \mathrm{t}^{2} \rightarrow \mathrm{t}=2.85 \mathrm{~s}\left(175^{\circ} \mathrm{C}\right)$

$31.1=1 / 29.81 \mathrm{t}^{2} \rightarrow \mathrm{t}=2.51 \mathrm{~s}$

$40.0-31.1=8.88=1 / 29.81 \mathrm{t}^{2} \rightarrow \mathrm{t}=1.345 \mathrm{~s}$

$1.68=1 / 29.81 \mathrm{t}^{2} \rightarrow \mathrm{t}=0.58 \mathrm{~s}$

$8.88-1.68=7.2=1 / 29.81 \mathrm{t}^{2} \rightarrow \mathrm{t}=1.21 \mathrm{~s}$

$9.33=1 / 29.81 \mathrm{t}^{2} \rightarrow \mathrm{t}=1.37 \mathrm{~s}$

The details of these calculations are given in Tables 1 and 2.

\section{Discussion}

After the manufacture of $\mathrm{NH}_{4} \mathrm{NO}_{3}$, the changing phases of $\mathrm{NH}_{4} \mathrm{NO}_{3}$ crystals have been shown using calculations for the prill tower. According to these calculations, cubic $\mathrm{NH}_{4} \mathrm{NO}_{3}$ crystals are formed after reaction at $175{ }^{\circ} \mathrm{C}$, tetragonal at $125{ }^{\circ} \mathrm{C}$, orthorhombic at $84,5{ }^{\circ} \mathrm{C}$, and orthorhombic at $32{ }^{\circ} \mathrm{C}$ ( Figures 1- 9)(Theoret, A., \& Sandorfy. 1963, pp. 57-61). The most important problem during fertilizer manifacture is temperature and the routinely used influent- cooling technique is expensive; application of this technique is not adequate for a prill tower. Therefore, nowadays, the used technique is the cooling- motor system. By using cooling motors, the duration that the substance remains on air is increased, because the velocity slowly decreases along with the motor's impact. For carrying out calculations here, we assume that the desired staying time is reached. So, initially, we calculate for a four- motor system by referring to a system already available in the industry ( Figure 10). Then, we calculate for a six- motor systems, of which, four are in the same direction, with two others in different directions (Figure 11). Using six- motors ensures that required temperature is reached and that we get a good economical value from the process. Another feature of our work is that we viewed each form of the $\mathrm{NH}_{4} \mathrm{NO}_{3}$ crystals by electron microscopy; the observations are in accordance with those reported in literature.

A scanning electron microscope (SEM) (JEOL Technics, Ltd, Jeol 6060) was used for observations. The working condition of this microscope was as follows: high- voltage separation power: $1 \sim 30 \mathrm{kV}$; magnification: 10 1 000 000; using the secondary electron image (SEI) mode $\sim$ backscattered electron image (BEI) mode, its resolution was $30 \mathrm{kV}$ (SEI) at $1.2 \mathrm{~nm}$ and $30 \mathrm{kV}$ (BEI) at $3.0 \mathrm{~nm}$. To produce images of surfaces, SEI was used as the first choice because in electron microscopes, the electrons directed on to the specimen produce two types of images. The first is the SEI, which is used to produce images of secondary electrons that originate after 
stimulating the specimen atoms, and the second is the BEI, which consists of the electrons that are backscattered from the specimen interaction volume by the elastic scattering interactions with the specimen atoms. SEI uses a topographical contrast, whereas, BEI creates the contrast according to the atomic numbers. In other words, with SEI, it is possible to examine the sample surface with reference to its form and, with BEI, with reference to the chemical differences. Therefore, we have used SEI in our studies.

Views of each of the $\mathrm{NH}_{4} \mathrm{NO}_{3}$ phase were taken under different working conditions. SEM figures of the cubic phase at $175{ }^{\circ} \mathrm{C}$ were taken at $15 \mathrm{kV}, * 2000,10 \mu \mathrm{m}, 12 \mathrm{wd}$ (working distance) ( Figure 12); SEM photographs of the tetragonal phase at $125{ }^{0} \mathrm{C}$ were taken at $10 \mathrm{kV}, * 1000,10 \mu \mathrm{m}, 27 \mathrm{wd}($ Figure 13), SEM photographs of the orthorhombic phase at $84.5^{0} \mathrm{C}$ were taken at $25 \mathrm{kV}, * 7500,1 \mu \mathrm{m}, 36 \mathrm{wd}$ (Figure 14).

The different phases of $\mathrm{NH}_{4} \mathrm{NO}_{3}$ formed on the prill tower are named as cubic, tetragonal, and orthorhombic. Three different crystal phases occur in the orthorhombic phase, two different crystal phases in the tetragonal phase, and only one constant- length phase in the cubic crystal phase. Each length was calculated as Á. Atomic border lengths of each crystal phase were measured on an X-ray spectrophotometer (Philips PW 2400 XRF-02/2062). Experimental working conditions were $220 \mathrm{~V}, 50 \mathrm{~Hz}$ and 50 W.55 W. Rolein P4-Comput The lengths between the atoms of each crystal phase are shown in Table 3 and the final connected shapes are shown in Figures 3,5, and 8. When we looked at these fertilizer solutions with various crystal phases using a binocular microscope under thermodynamic conditions, the changes in the building of prill were seen, as shown in Figures 1,4 , and 7 . The values are presented according to the view quality. The prill temperature of $\mathrm{NH}_{4} \mathrm{NO}_{3}$ decreases and the particles pick up heat from each other under influence of vacuum, -with elimination of water, producing spherical crystalline forms. According to the results of the experiments, the volume of $\mathrm{NH}_{4} \mathrm{NO}_{3}$ decreases with decreasing temperature and water content. Microscopic examination was carried out on a Nikon E100 binocular microscope equipped with a 10- w halogen lamp under $800 \times$ magnification. Only one constant-length unit was found in the crystal. Volume of a unit of cubic phase at 169, and $1250 \mathrm{C}$ is $83.2 \AA$ ( Brusset, Leveau, Spinat, Trani, Verollet, 2002, pp.3). Eight unit lengths are present inside these crystals. The volume of each unit composing the crystal is different; therefore, the volumes of the units are not similar. Consequently, the water content of the fertilizer in the prill tower changes, and cyristal phases with different lengths are formed. The values for density of $\mathrm{NH}_{4} \mathrm{NO}_{3}$ at different temperatures and concentrations are in Table 1. The density of $\mathrm{NH}_{4} \mathrm{NO}_{3}$ could not be measured because $\mathrm{NH}_{4} \mathrm{NO}_{3}$ has a lower concentration and higher temperature at conditions shown in Table 4. At higher concentrations, the solutions became saturated, and hence they are shown with the maximum values.

\section{Conclusion}

According to the results of the experiments, the volume of $\mathrm{NH}_{4} \mathrm{NO}_{3}$ decreases with decreasing temperature and water content. Using six- motors ensures that required temperature is reached and that we get a good economical value from the process. A six- motor system is preferable to a four- motor one, we will carry out further calculations for the six- motor system.

\section{Acknowledgements}

Ahmet Ozan Gezerman is thankful to his mother "Rukiye Gezerman" for her inspiration.

\section{References}

Brusset, Leveau, Spinat, Trani, \& Verollet. (2002). Le Nitrate D’ammonium. [Online] Available: www.ensiacet.fr/web_a7/web_travail/web_a7/ensia7_fr/formation/dossier_a7/nitrate_d_ammonium.pdf (February, 2002)

Derbentli, T. (1996). Muhendislik Yaklasimi ile Termodinamik. (1 st ed.). Istanbul: Literatur, (Bolum 3)

Jacobsen, Lemmon, Penoncello, Shan, \& Wright. (2000). Thermophysical Properties of Fluids and Materials. Idaho: E- Publishing Inc. pp. 140-152

Kakac, S., \& Yuncu, H. (1999). Temel Isi Transferi. Ankara: Bilim, (Bolum 6)

Kucuksahin, F. (1989). Teknik Formuller. (1 st ed.). Istanbul: Beta, (Bolum5)

Theoret, A., \& Sandorfy. (1963). Infrared Spectra And Crystalline Phase Transitions Of Ammonium Nitrate. [Online]

http://article.pubs.nrc-cnrc.gc.ca/RPAS/rpv?hm=HInit\&journal=cjc\&volume=42\&afpf=v64-009.pdf

Available: 


\section{Reaction Schemes}

$$
\mathrm{NH}_{3}+\mathrm{HNO}_{3} \rightarrow \mathrm{NH}_{4} \mathrm{NO}_{3}
$$

Scheme-I

Table 1. The performance of fertilizer after release from prill case, until leaving four- motor tower

\begin{tabular}{|l|l|l|}
\hline Temperature $\left({ }^{0} \mathrm{C}\right)$ & Height $(\mathrm{m})$ & Time $(\mathrm{s})$ \\
\hline 175 & 40 & 4.61 \\
\hline $175-125$ & $40.00-13.33=26.67$ & 2.33 \\
\hline 125 & 13.33 & 1.65 \\
\hline $125-84.5$ & $13.33-10.8=2.53$ & 0.718 \\
\hline 84.5 & 10.8 & 1.48 \\
\hline $84.5-32$ & 18.04 & 1.91 \\
\hline
\end{tabular}

Table 2. The performance of fertilizer after release from prill case, until leaving six- motor tower

\begin{tabular}{|l|l|l|}
\hline Temperature $\left({ }^{0} \mathrm{C}\right)$ & Height $(\mathrm{m})$ & Time $(\mathrm{s})$ \\
\hline 175 & 40 & 4.61 \\
\hline $175-125$ & $40-8.88=31.1$ & 2.51 \\
\hline 125 & 8.88 & 1.345 \\
\hline $125.0-84.5$ & $8.88-7.2=1.68$ & 0.58 \\
\hline 84.5 & 7.2 & 1.21 \\
\hline $84.5-32$ & 9.33 & 1.37 \\
\hline
\end{tabular}

Table 3. Crystallography of $\mathrm{NH}_{4} \mathrm{NO}_{3}$ measured at atmosphere pressure

\begin{tabular}{|l|l|l|l|l|l|}
\hline Temperature & \multicolumn{1}{|c|}{$\begin{array}{c}\text { Crystal } \\
\text { structure }\end{array}$} & $\begin{array}{c}\text { Unit parameter of } \\
\text { crystal structure } \\
(\AA)\end{array}$ & $\begin{array}{l}\text { Number of unit } \\
\text { in crystal } \\
\text { structure }\end{array}$ & $\begin{array}{c}\text { Volume of unit } \\
\text { in Crystal } \\
\text { structure }\left(\AA^{3}\right)\end{array}$ & $\begin{array}{c}\text { Volumes of crystal } \\
\text { structure with eight } \\
\text { unit }\left(\AA^{3}\right)\end{array}$ \\
\hline $125-175$ & Cubic & $\mathrm{a}=4.366$ & 1 & 83.2 & 665.6 \\
\hline $84.2-125.2$ & Tetragonal & $\mathrm{a}=5.696$ & 2 & 159.6 & 638.4 \\
\hline $32.1-84.2$ & Orthorhombic & $\begin{array}{l}\mathrm{a}=7.140 \\
\mathrm{~b}=7.650\end{array}$ & 4 & 318.4 & 636.9 \\
& & & & & \\
& & & & & \\
\end{tabular}

Table 4. Density of $\mathrm{NH}_{4} \mathrm{NO}_{3}$ at different temperatures and concentrations

\begin{tabular}{|c|c|c|c|c|c|c|c|c|c|c|c|}
\hline $\begin{array}{l}\text { Temperature } \\
\left({ }^{0} \mathrm{C}\right)\end{array}$ & $20 \%$ & $30 \%$ & $40 \%$ & $50 \%$ & $60 \%$ & $70 \%$ & $80 \%$ & $90 \%$ & $94 \%$ & $97 \%$ & $99 \%$ \\
\hline 20 & 1.0830 & 1.1275 & 1.1750 & 1.2250 & 1.2785 & \multicolumn{6}{|c|}{ overflowed limit of solubility-- } \\
\hline 40 & 1.0725 & 1.1160 & 1.1630 & 1.2130 & 1.266 & 1.3220 & \multicolumn{5}{|c|}{ overflowed limit of solubility---_- } \\
\hline 60 & 1.0620 & 1.1045 & 1.1515 & 1.2005 & 1.252 & 1.3090 & 1.3685 & \multicolumn{4}{|c|}{ overflowed limit of solubility------ } \\
\hline 80 & 1.0550 & 1.0935 & 1.1390 & 1.1875 & 1.239 & 1.2960 & 1.3555 & \multicolumn{4}{|c|}{ overflowed limit of solubility----- } \\
\hline 100 & 1.0410 & 1.0820 & 1.1270 & 1.1745 & 1.226 & 1.2825 & 1.3420 & \multicolumn{4}{|c|}{ 1.4075---------_-“-------------------- } \\
\hline 120 & & & & gas & & & 1.3285 & 1.39 & \multicolumn{3}{|c|}{1.4210} \\
\hline 140 & & & & gas & & & & & 1.3785 & 1.4065 & 1.4285 \\
\hline 160 & & & & gas & & & & & 1.3940 & 1.4165 & 1.4325 \\
\hline 180 & & & & gas & & & & & & 1.4060 & 1.4225 \\
\hline 200 & & & & gas & & & & & & & 1.4121 \\
\hline 220 & & & & gas & & & & & & & 1.4030 \\
\hline
\end{tabular}




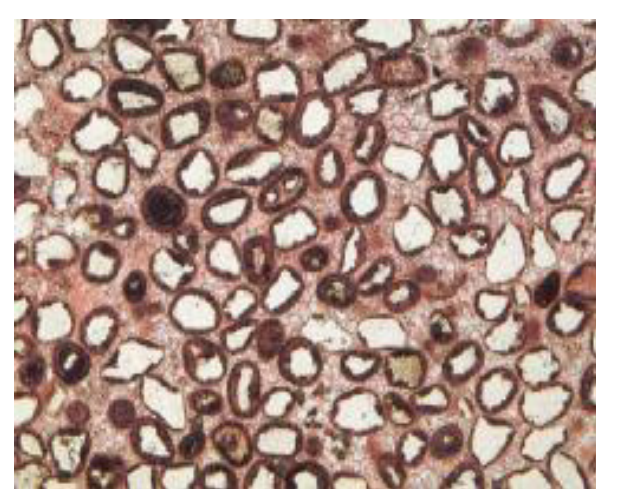

Figure 1. View of $\mathrm{NH}_{4} \mathrm{NO}_{3}$ in the orthorhombic crystal phase, as seen using a binocular microscope at $84.5{ }^{\circ} \mathrm{C}$

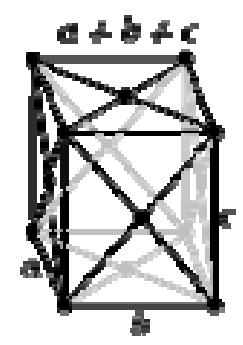

Figure 2. Geometric view of $\mathrm{NH}_{4} \mathrm{NO}_{3}$ in the orthorhombic phase ${ }^{n+} 81.5{ }^{0} \mathrm{C}$
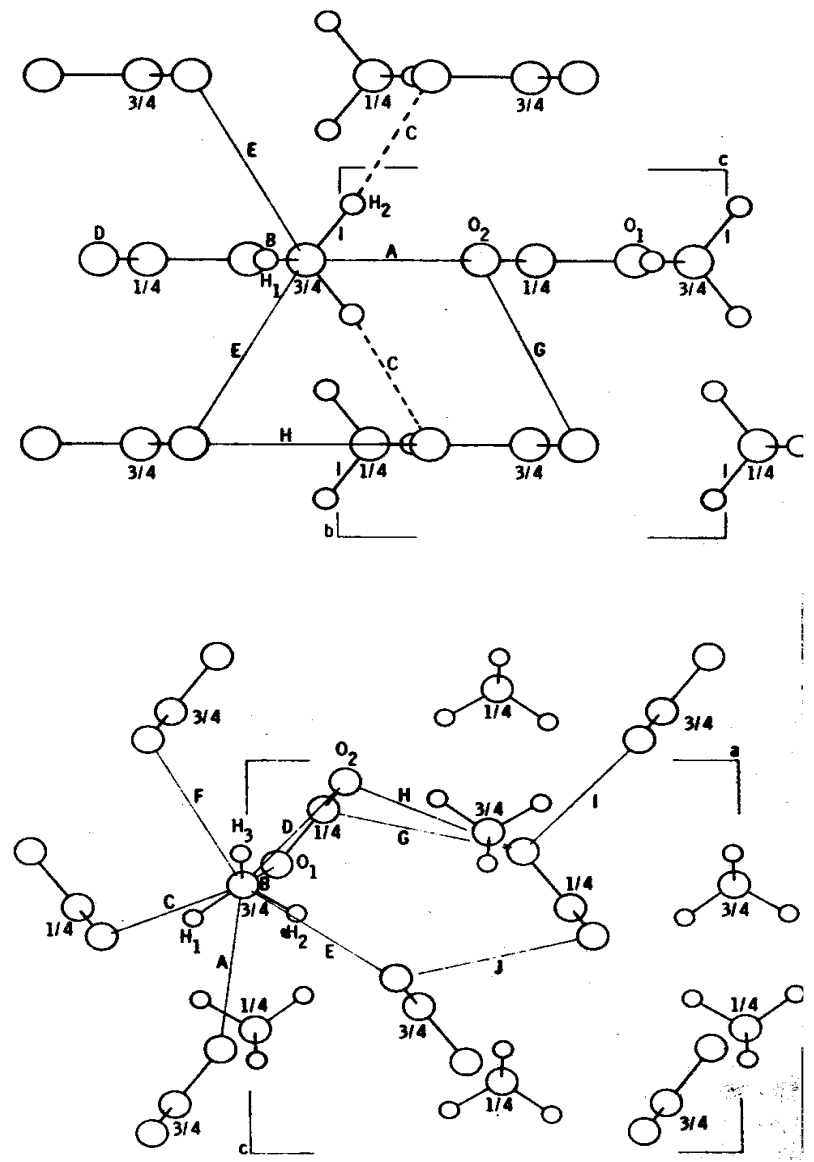

Figure 3. Space shape of $\mathrm{NH}_{4} \mathrm{NO}_{3}$ in the orthorhombic phase at $84.5^{\circ} \mathrm{C}$ 


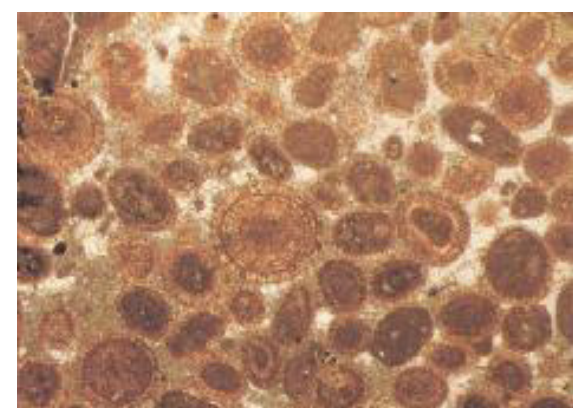

Figure 4. View of $\mathrm{NH}_{4} \mathrm{NO}_{3}$ in the tetragonal crystal phase, as seen through a binocular microscope at $125{ }^{\circ} \mathrm{C}$

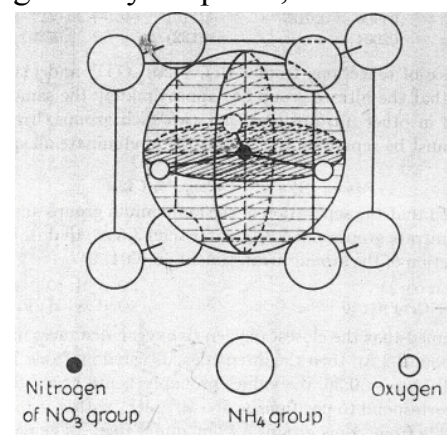

Figure 5. Space shape of $\mathrm{NH}_{4} \mathrm{NO}_{3}$ in the tetragonal phase at $125{ }^{\circ} \mathrm{C}$

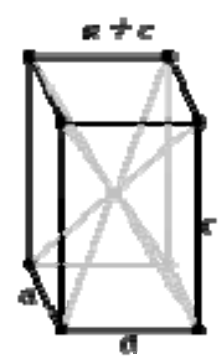

Figure 6. Geometric view of $\mathrm{NH}_{4} \mathrm{NO}_{3}$ in the tetragonal phase at $125{ }^{\circ} \mathrm{C}$

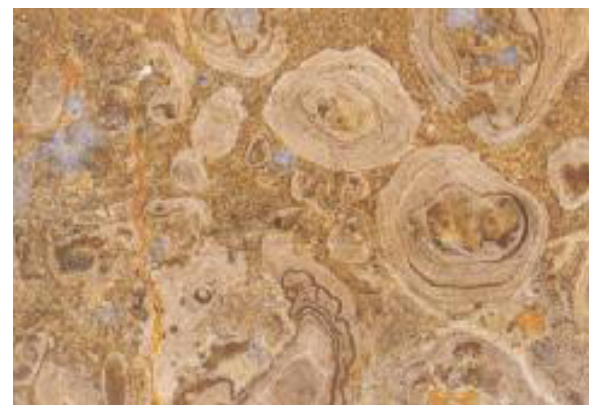

Figure 7. View of $\mathrm{NH}_{4} \mathrm{NO}_{3}$ in the cubic cyristal phase, as seen through a binocular microscope at $175{ }^{\circ} \mathrm{C}$

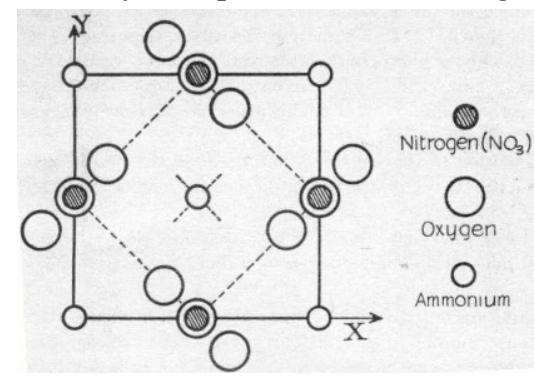

Figure 8. Space shape of $\mathrm{NH}_{4} \mathrm{NO}_{3}$ in the cubic phase at $175{ }^{\circ} \mathrm{C}$ 


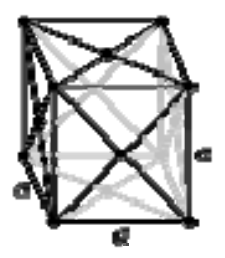

Figure 9. Geometric view of $\mathrm{NH}_{4} \mathrm{NO}_{3}$ in the cubic phase at $175^{\circ} \mathrm{C}$

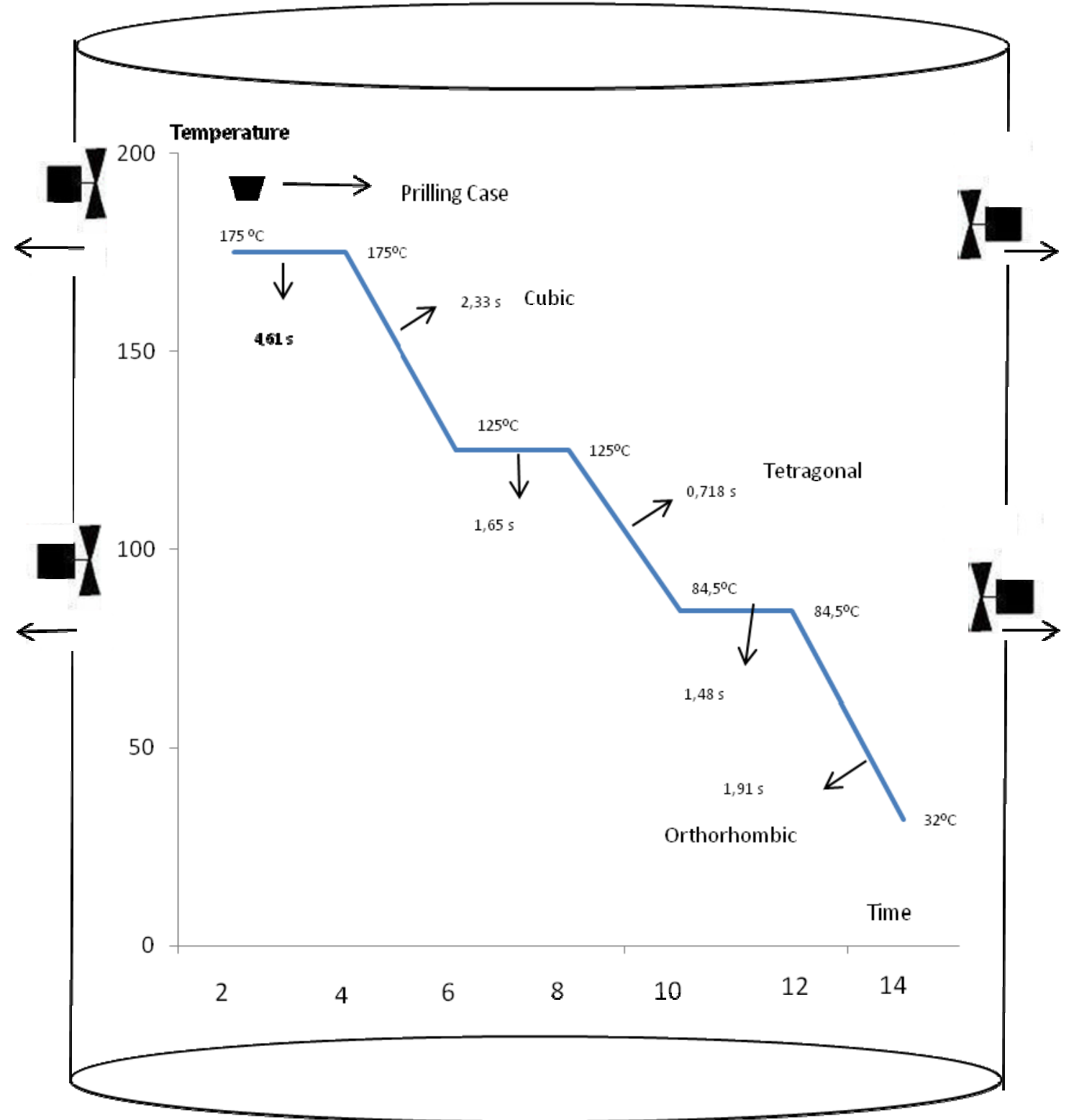

Figure 10. Physicochemical behavior of prilled fertilizer as it goes down a prill tower with a four- motor system. 


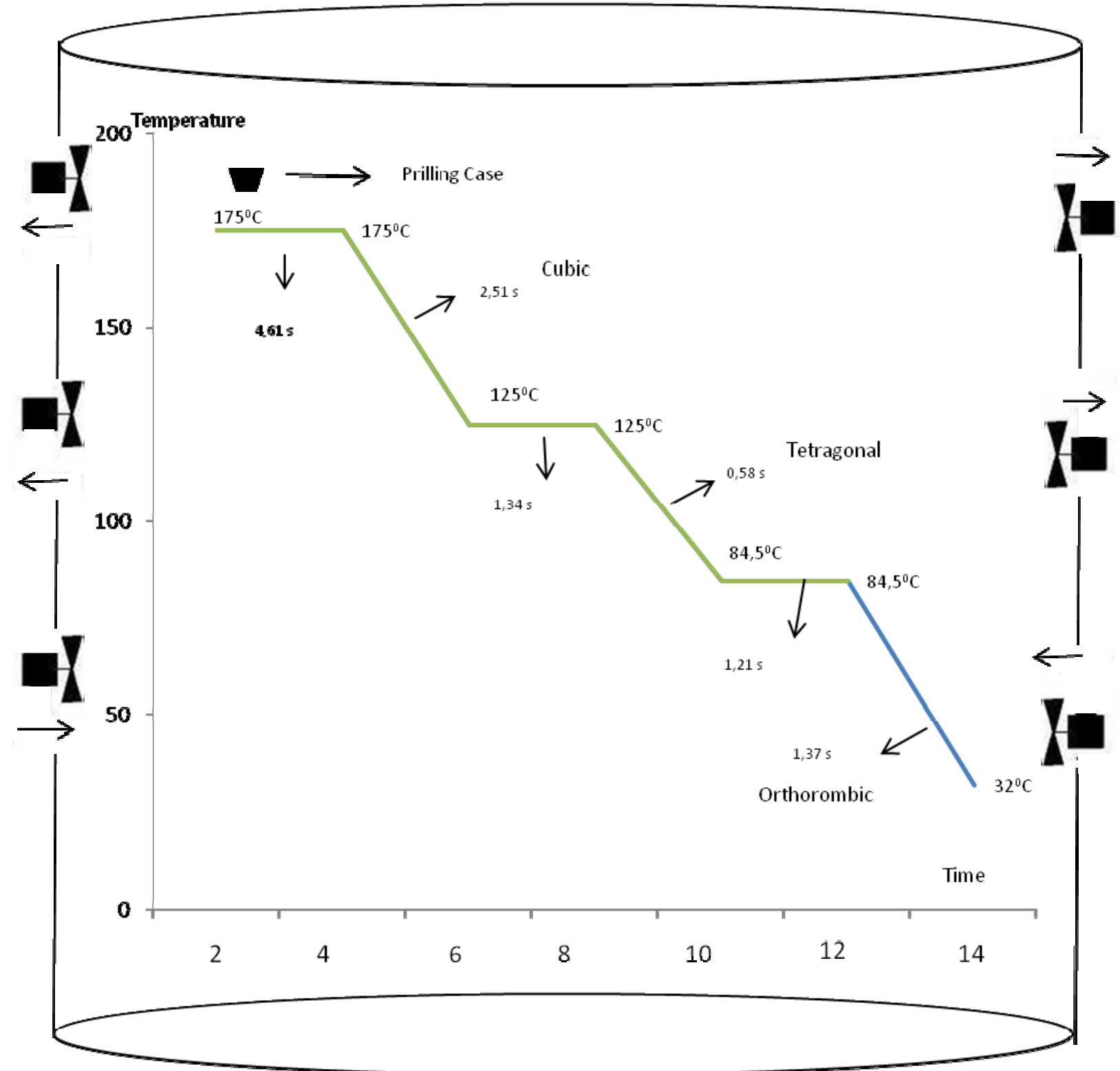

Figure 11. Physicochemical behavior of prilled fertilizer as it goes down a prill tower with a six- motor system 


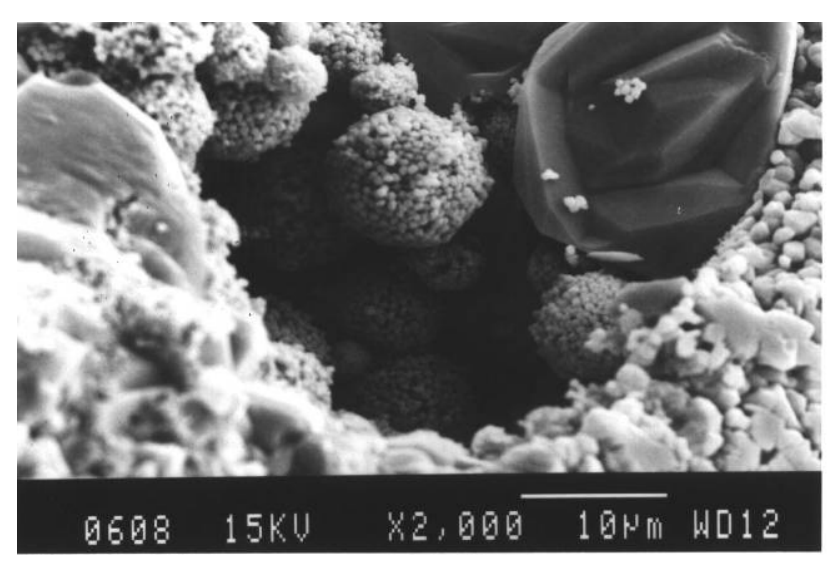

Figure 12. SEM photographs of the $\mathrm{NH}_{4} \mathrm{NO}_{3}$ at $175{ }^{\circ} \mathrm{C}$

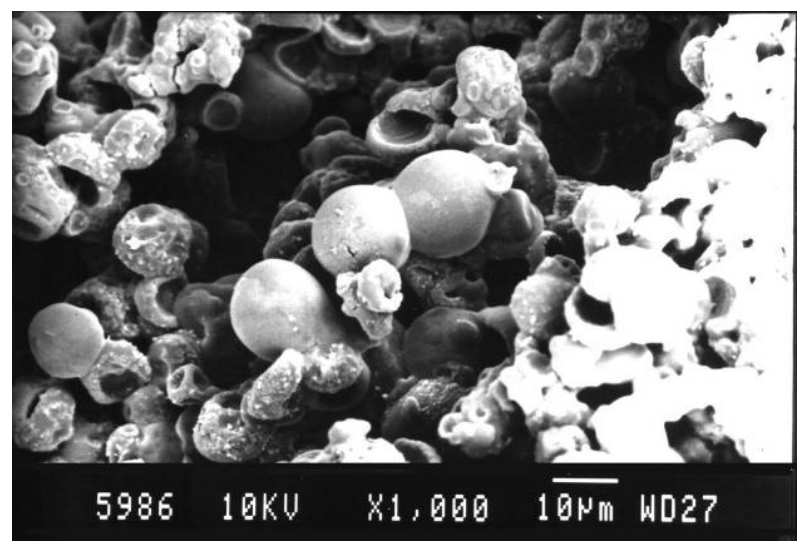

Figure 13. SEM photographs of the $\mathrm{NH}_{4} \mathrm{NO} 3$ at $125^{\circ} \mathrm{C}$

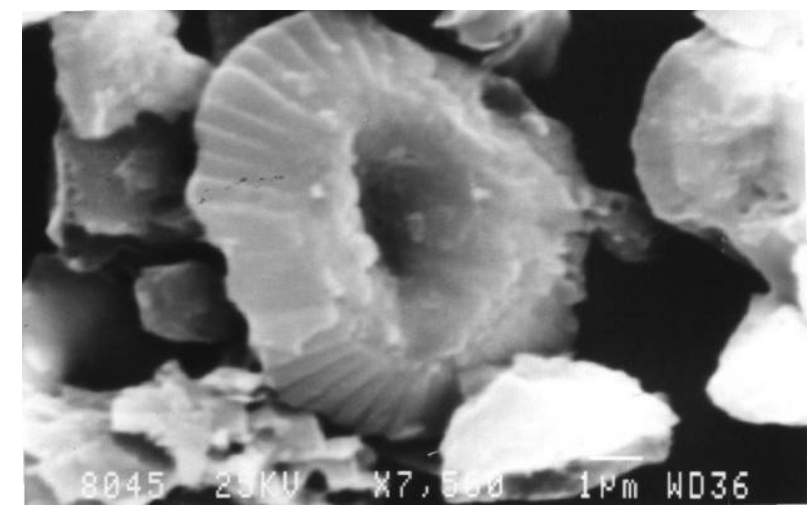

Figure 14. SEM photographs of the $\mathrm{NH}_{4} \mathrm{NO}_{3}$ at $84.5^{\circ} \mathrm{C}$ 